\title{
AINDA DEVEMOS FALAR DE VIRTUDE CÍVICA? O LUGAR DA MORAL NA POLÍTICA REPUBLICANA SEGUNDO ROUSSEAU E SANDEL
}

\author{
Renato Moscateli $^{1}$
}

\section{Resumo:}

Em diversas de suas obras, Jean-Jacques Rousseau ressaltou a importância política dos componentes morais imprescindíveis a uma república bem ordenada, onde a virtude deveria estar presente em todos os cidadãos, a fim de que o interesse comum prevalecesse. No Discurso sobre as ciências e as artes, por exemplo, ao comparar sua época com os tempos em que os espartanos e os romanos deram grandes exemplos de patriotismo, o filósofo comentou que "os políticos antigos falavam sem cessar de costumes e de virtude; os nossos só falam de comércio e de dinheiro", enfatizando assim uma diferença que demonstrava, em sua visão, o quanto a política havia se deteriorado ao longo dos séculos. Em contraposição a esse declínio, o pensador genebrino conferiu um lugar central aos costumes e à opinião pública, à religião civil e à educação para fomentar a união da comunidade e deliberações soberanas nas quais a vontade geral se expressasse claramente, em qualquer que seja o Estado republicano digno desse nome. Em nossa própria época, é digno de nota que o filósofo americano Michael J. Sandel tem produzido textos que denunciam o esvaziamento do espaço público de conteúdos morais e religiosos - segundo ele, uma consequência da proposta liberal de neutralidade frente às distintas concepções de bem dos cidadãos -, o que o autor entende ser nocivo às democracias contemporâneas, visto que leva ao empobrecimento das deliberações políticas. Para ele, é fundamental que tais conteúdos possam contribuir para promover as virtudes necessárias ao exercício da cidadania republicana, sem as quais as práticas do autogoverno seriam inviáveis. Diante disso, minha intenção é tomar as ideias de Rousseau e de Sandel como referência para discutir o lugar que a moral pode ocupar na política das repúblicas, sobretudo no contexto atual, não somente como um fator potencialmente positivo, mas também em termos de certos riscos que sua presença no espaço público é capaz de trazer.

Palavras-chave: Política. Moral. Virtude Cívica. Rousseau. Sandel.

\section{SHOULD WE STILL TALK ABOUT CIVIC VIRTUE? THE PLACE OF MORALITY IN REPUBLICAN POLITICS ACCORDING TO ROUSSEAU AND SANDEL}

\begin{abstract}
:
In several of his works, Jean-Jacques Rousseau stressed the political importance of the moral components essential to a well-ordered republic, where virtue should be present in all citizens, so that the common interest prevails. In his Discourse on the Sciences and the Arts, for example, by comparing his epoch to the times when Spartans and Romans gave great examples of patriotism, the philosopher commented that "Ancient politicians talked incessantly about morality and virtue; our politicians talk only about business and money", thus emphasizing a difference that showed, in his view, how much politics had deteriorated over the centuries. In opposition to such decline, the Geneva's thinker gave a central place to customs and public opinion, to civil religion and education in order to foster community's unity and sovereign deliberations in which the general will expresses itself clearly, in all the republican states worthy of this name. In our own time, it's noteworthy that the American philosopher Michael J. Sandel has produced texts to denounce the emptying of the public space regarding to moral and religious content - according to him, a consequence of the liberal proposal of neutrality towards citizens' different conceptions of good - which the author considers to be harmful to contemporary democracies, since it leads to the impoverishment of political deliberations. For him, it's fundamental that such content can contribute to promote the virtues necessary for the exercise of republican citizenship, without which the practices of self-government would be infeasible. In the light of this, my intention is to take the ideas of Rousseau and Sandel as a reference to discuss the place that morality can occupy in republics' politics, especially in the present context, not only as a potentially positive factor, but also by considering certain risks that its presence in the public space is capable of bringing.
\end{abstract}

1 Doutor em Filosofia pela Universidade Estadual de Campinas. Professor da Faculdade de Filosofia da Universidade Federal de Goiás. E-mail: rmoscateli@hotmail.com 
Keywords: Politics. Morality. Civic Virtue. Rousseau. Sandel.

Em diversas de suas obras, Jean-Jacques Rousseau ressaltou a importância política dos componentes morais imprescindíveis a uma república bem ordenada, onde a virtude deveria estar presente em todos os cidadãos, a fim de que o interesse comum prevalecesse. No Discurso sobre as ciências e as artes, por exemplo, ao comparar sua época com os tempos em que os espartanos e os romanos deram grandes exemplos de patriotismo, o filósofo comentou que "os políticos antigos falavam sem cessar de costumes e de virtude; os nossos só falam de comércio e de dinheiro" (Rousseau, 2003, p. 19)², enfatizando assim uma diferença que demonstrava, em sua visão, o quanto a política havia se deteriorado ao longo dos séculos. Em contraposição a esse declínio, o pensador genebrino conferiu um lugar central aos costumes e à opinião pública, à religião civil e à educação para fomentar a união da comunidade e deliberações soberanas nas quais a vontade geral se expressasse claramente, em qualquer que seja o Estado republicano merecedor desse nome. Em nossa própria época, é digno de nota que o filósofo americano Michael J. Sandel tem produzido textos que denunciam o esvaziamento do espaço público de conteúdos morais e religiosos - segundo ele, uma consequência da proposta liberal de neutralidade frente às distintas concepções de bem dos cidadãos $^{3}-$, o que o autor entende ser nocivo às democracias contemporâneas, visto que leva ao empobrecimento das deliberações políticas. Para ele, é fundamental que tais conteúdos possam contribuir para promover as virtudes necessárias ao exercício da cidadania republicana, sem as quais as práticas do autogoverno seriam inviáveis. Diante disso, minha intenção é tomar as ideias de Rousseau e de Sandel como referência para discutir o lugar que a moral e a religião podem ocupar na política das repúblicas, sobretudo no contexto atual, não somente como um fator potencialmente positivo, mas também em termos de certos riscos que sua presença no espaço público é capaz de trazer ${ }^{4}$.

No início do livro Democracy's Discontent, Sandel defende a necessidade de se revitalizar a vertente cívica da liberdade, associada por ele à tradição do republicanismo. Nesta tradição, diz o autor, "é central a ideia de que a liberdade depende da participação no autogoverno", isto é, de “deliberar junto com seus concidadãos sobre o bem comum e ajudar a

2 As traduções para o português dos excertos das obras de Rousseau citados neste artigo são de minha responsabilidade. O mesmo vale para os excertos das obras de Sandel.

3 Neste sentido, as teses liberais do também filósofo americano John Rawls foram alvos centrais das críticas de Sandel, tanto na versão originalmente exposta em Uma teoria da justiça (Rawls, 2000a), quanto em sua versão revisada presente em O liberalismo político (Rawls, 2000b).

4 Uma versão preliminar deste artigo foi apresentada durante as atividades do III Congresso Nacional JeanJacques Rousseau UFMA: Estética e Representação, realizado em São Luís de 25 a 27 de junho de 2018. Expresso aqui meus agradecimentos aos organizadores do evento pela oportunidade de discutir o texto.

\begin{tabular}{|l|l|l|l|l|}
\hline Govista Qialectus & Ano 8 & n. 15 & Agosto - Dezembro 2019 & p. 288-303 \\
\hline
\end{tabular}


moldar o destino da comunidade política" (Sandel, 1996, p. 5). Tais palavras ecoam as de numerosos pensadores republicanos de épocas passadas, incluindo as de Rousseau, o qual havia orgulhosamente se filiado a essa linhagem política no século XVIII ao conceber a república como a única forma legítima de Estado, dentro da qual os homens podem ser livres e iguais perante as leis que eles mesmos instituíram conjuntamente como membros do poder soberano ${ }^{5}$.

Para Rousseau, assim como para Sandel, essa liberdade republicana envolve um tipo de vida política que não se encontra em qualquer tempo ou lugar. Refletindo sobre suas condições de existência, tal como Rousseau havia feito em obras como o Contrato Social, Sandel confronta dois questionamentos: é possível reviver os ideais republicanos? É desejável fazer isto? O autor reconhece ser comum a objeção de que esses ideais são propícios a pequenas comunidades, mas não aos grandes e complexos Estados contemporâneos, os quais são integrados em amplos cenários políticos e econômicos. Neste ponto de vista, eles assumem um ar de nostalgia, e embora possam servir como contraponto crítico ao liberalismo, pouco teriam a oferecer de efetivo para resolver os problemas da sociedade atual. Ademais, para muitos parece indesejável tentar trazê-los novamente a um contexto político caracterizado pela república procedimental, no qual certa perda de sentido de comunidade e de práticas de autogoverno foi compensada pela difusão da tolerância e pelo espaço de escolha individual permitidos pelo liberalismo.

Outra objeção à teoria política republicana mencionada por Sandel é a de que ela demanda dos cidadãos virtudes importantes para o exercício do autogoverno e a deliberação sobre o bem comum, as quais não seriam encontradas em qualquer pessoa. Por isto, já houve quem pensasse que o direito de cidadania deveria ser concedido de modo mais restrito, visando àqueles indivíduos que são capazes de alcançar tais virtudes e excluindo os que não são ${ }^{6}$. Porém, Sandel argumenta que essa tese da impossibilidade de se corrigir a inaptidão à virtude cívica é criticada pelos republicanos para os quais os bons cidadãos não são natos, mas formados por meio da educação política. Tal é a visão presente nas versões democráticas do pensamento republicano que surgiram a partir do Iluminismo (Sandel, 1996, p. 319).

Isto nos remete às ideias de Rousseau. Como foi dito, desde o Discurso sobre as ciências $e$ as artes o autor recorreu às repúblicas da Antiguidade como contrapontos históricos aos povos modernos. Aos olhos do filósofo, tais corpos políticos bem ordenados,

5 Ver o Contrato Social, especialmente os capítulos 6, 7 e 8 do livro 1, e o capítulo 6 do livro 2.

6 Exemplos de grupos politicamente excluídos mencionados por Sandel seriam as mulheres, os escravos e os estrangeiros, como na política grega analisada por Aristóteles; ou então os pobres, os negros e os imigrantes na América do século XIX.

\begin{tabular}{|c|c|c|c|c|}
\hline Revista Dialectus & Ano 8 & n. 15 & Agosto - Dezembro 2019 & p. $288-303$ \\
\hline
\end{tabular}


Esparta e Roma especialmente, mostravam que os homens podiam ser educados para a vida em sociedade de um modo que os ligava fortemente à busca do bem comum junto a seus compatriotas. Sem dúvida, esse processo formativo implicava uma mudança bastante substantiva no modo de ser dos indivíduos, para que deixassem de ser unidades independentes, dotadas apenas de interesses particulares, e pudessem integrar uma comunidade na qual a intersecção dos interesses de todos resultasse na vontade geral, fonte da lei e regra da justiça para cada membro do Estado ${ }^{7}$. Era essa educação pública que, na visão de Rousseau, garantiria as condições de existência da liberdade e da igualdade dos membros do pacto originador da soberania popular, pois faria com que deixassem de ser apenas fruto daquilo que a natureza havia incutido neles, passando a incorporar novos costumes, hábitos e paixões direcionados à república, como se pode ler no verbete Economia Moral e Política:

\begin{abstract}
Se as crianças são educadas em comum no seio da igualdade, se elas são imbuídas das leis do Estado e das máximas da vontade geral, se elas são instruídas a respeitálas acima de todas as coisas, se elas são cercadas de exemplos e de objetos que lhes falam sem cessar da mãe terna que os alimenta, do amor que tem por elas, dos bens inestimáveis que recebem dela, e do retorno que lhe devem, não duvidemos de que elas aprendam assim a se gostar mutuamente como irmãos, a querer sempre aquilo que a sociedade quer, a substituir a estéril e vã tagarelice dos sofistas por ações de homens e de cidadãos, a se tornar, um dia, os defensores e os pais da pátria, da qual eles foram, por tanto tempo, as crianças. (Rousseau, 2003, p. 261). ${ }^{8}$
\end{abstract}

Neste sentido, encontramos em Rousseau uma concepção de cidadania que ultrapassa a mera ideia de um direito conferido a quem nasce dentro dos limites de um Estado. Para o genebrino, ser cidadão trazia consigo as mais sérias responsabilidades e exigia uma poderosa virtude, pois significava o status de quem participava diretamente da autoridade máxima dentro da república, isto é, do exercício da soberania. Como tal, cabia ao cidadão deliberar sobre as leis tendo sempre em vista o melhor interesse da comunidade, o que não seria possível se ele não fosse capaz do tipo de reflexão requerido para generalizar sua vontade $^{9}$ e abranger a totalidade do corpo político ao dar seus votos na assembleia popular; e

7 Ver o Contrato Social, livro 2, capítulo 7. Acerca da vontade geral como intersecção das vontades dos cidadãos, ver Reis (2010).

8 Sobre a educação pública, além desse verbete escrito por Rousseau para a Enciclopédia, ver também o capítulo 4 das Considerações sobre o governo da Polônia.

9 Também é válido ressaltar, conforme explica Bruno Bernardi, que Rousseau via a necessidade de que a generalização da vontade passasse não só por um exercício da razão pública, mas igualmente pela expansão dos sentimentos em prol da comunidade: “o processo de generalização das vontades particulares, do qual depende a constituição de uma ordem política legítima, é um processo cognitivo (fazer com que cada um reconheça no interesse comum o seu próprio), mas por isso mesmo, e não apesar disso, nem mesmo ao lado disso, esse processo requer condições propriamente passionais. Ele está longe de fazer do 'silêncio das paixões' a condição da 'vontade geral do gênero humano', como Diderot o fez, ao retomar a expressão de Malebranche, no artigo 'Direito natural' da Enciclopédia. Para Rousseau, o processo cognitivo de generalização implica afetos de generalização: é preciso que os sentimentos se ampliem para que as ideias se

\begin{tabular}{|l|l|l|l|l|}
\hline Q Rovista Dialectus & Ano 8 & n. 15 & Agosto-Dezembro 2019 & p. 288-303 \\
\hline
\end{tabular}


isto, por sua vez, dificilmente ocorreria se não nele não houvesse uma profunda identificação moral e afetiva com a pátria ${ }^{10}$. Tal identidade, ou caráter nacional ${ }^{11}$ nos termos de Rousseau, embora fosse tão artificial quanto a vida em sociedade, não deixava de se transformar em algo natural para os indivíduos que dela compartilhavam, visto que ficava gravada em seus corações e os conduzia com uma força superior à das leis propriamente ditas ${ }^{12}$. Isto seria imprescindível para gerar o engajamento com os assuntos públicos requerido à preservação da saúde do Estado, transformando cada cidadão em um baluarte contra a corrupção da vida política que ocorre sempre que prolifera o desinteresse pelo bem comum e o predomínio das vontades particulares.

Sandel também partilha a compreensão da importância do projeto educativo de formar cidadãos virtuosos para a república, mas diz que tal reconhecimento não deveria nos cegar para os perigos existentes nele, especialmente em sociedades tão plurais como as contemporâneas, pois isto levanta o problema de uma possível coerção sobre os cidadãos para moldá-los ao papel que se espera deles na comunidade política. O filósofo americano ilustrou esse risco remetendo justamente ao pensamento de Rousseau e dizendo que a "formação das almas" que ele defendia, isto é, uma verdadeira mudança da natureza humana para transformar os indivíduos em partes do Estado ${ }^{13}$, podia ser excessiva em seus efeitos (Sandel, 1996, p. 319). De fato, não se pode negar que, para Rousseau,

[é] a educação que deve dar às almas a força nacional, e dirigir de tal forma suas opiniões e seus gostos que elas sejam patriotas por inclinação, por paixão, por necessidade. Ao abrir os olhos, uma criança deve ver a pátria, e até a morte não deve

estendam (...). Assim como o Emílio desenvolve uma pedagogia das paixões individuais, o Contrato Social precisa de uma política das paixões sociais, não para colocá-las no lugar das luzes públicas, mas para permitir que estas se desenvolvam. Toda a questão, então, é saber quais paixões têm esse poder de generalização. A resposta de Rousseau é clara: são as paixões que desenvolvem no eu sentimentos expansivos. São as paixões da liberdade e da igualdade (Contrato Social II, 1), o amor pela pátria também (no verbete Economia Política). Quais paixões colocam-se, inversamente, como obstáculo à generalização? As paixões que estreitam e fecham o indivíduo sobre si mesmo (Contrato Social III, 15)" (Bernardi, 2010).

10 Ainda no verbete Economia Moral e Política, lemos que "[não] basta dizer aos cidadãos que sejam bons, é preciso ensiná-los a sê-lo. E o próprio exemplo, que nesse tocante é a primeira lição, não é o único meio que se deve empregar. O amor pela pátria é o mais eficaz, pois (...) todo homem é virtuoso quando sua vontade particular está de acordo com a vontade geral, e nós queremos de bom grado aquilo que querem as pessoas de que gostamos" (Rousseau, 2003, p. 254). Acerca desse caráter constitutivo da identidade cívica em Rousseau, ver Moscateli (2012).

11 No Projeto de constituição para a Córsega, lemos que a primeira regra a ser seguida no tocante às leis e aos costumes de um povo é o caráter nacional: "Todo povo tem ou deve ter um caráter nacional, e se lhe falta isto, é preciso começar por lhe dar um" (Rousseau, 2003, p. 913). Nas Considerações sobre o governo da Polônia, o autor defende que "[s]ão as instituições nacionais que formam o gênio, o caráter, os gostos e os costumes de um povo, que o fazem ser ele e não um outro, que lhe inspiram esse ardente amor pela pátria fundado sobre hábitos impossíveis de se desenraizar, que o fazem morrer de enfado entre os outros povos, em meio às delícias das quais ele é privado no seu" (Rousseau, 2003, p. 960).

12 Acerca do valor inestimável dos costumes e da opinião pública como um tipo de lei especial a reger as ações dos cidadãos, ver o Contrato Social, livro 2, capítulo 12.

13 Ver o Contrato Social, livro 2, capítulo 7, e o Emílio, início do livro 1.

\begin{tabular}{|l|l|l|l|l|}
\hline Q Rovista Dialectus & Ano 8 & n. 15 & Agosto - Dezembro 2019 & p. 288-303 \\
\hline
\end{tabular}


ver nada mais além dela. Todo verdadeiro republicano suga, com o leite de sua mãe, o amor pela pátria, quer dizer, pelas leis e pela liberdade. Este amor faz toda a sua existência; ele só vê a pátria, só vive por ela; logo que está sozinho, ele é nulo; logo que não tem mais pátria, ele não existe mais, e se não está morto, é pior do que isto $(2003 \text {, p. } 966)^{14}$.

Todavia, na análise de afirmações como essa, é preciso ter em mente pelo menos dois pontos relevantes: em primeiro lugar, que Rousseau concebia a república inspirando-se, em boa medida, em exemplos de cidades da Antiguidade, pensando-a como um Estado viável somente se a população fosse pequena o bastante para que os cidadãos pudessem exercer a soberania - ou seja, o poder legislativo - diretamente, conhecendo uns aos outros como compatriotas e partícipes de um modo de vida comum, com costumes e valores semelhantes; em segundo lugar, se considerarmos o contexto em que o genebrino escreveu suas obras - no qual, conforme ele próprio, parecia não haver mais pátrias nem cidadãos ${ }^{15}-$, uma ênfase tão marcante na educação cívica patriótica tornava-se necessária, entre outros motivos, como estratégia para confrontar e criticar os malefícios do alheamento político de povos subjugados pelos governos despóticos que o autor enxergava como os mais comuns em seu tempo.

Beneficiado pela perspectiva de mais de duzentos anos de história republicana em seu próprio país, bem como pelo conhecimento dos excessos cometidos por diversos regimes autoritários do século XX no intuito de fortalecer a identidade nacional de seus povos, Sandel está em condições de afirmar que a educação dos cidadãos não precisava ser tão rigorosa quanto a proposta por Rousseau, mas poderia funcionar como nos EUA do século XIX, a primeira grande república da era moderna, quando as condições permitiram que se cultivassem virtudes como a preocupação com a comunidade, a independência e o juízo necessários para deliberar sobre o bem comum. Essa formação ocorria, nas palavras de Sandel, por meio de uma "mistura complexa de persuasão e habituação, o que Tocqueville chamou de 'a lenta e silenciosa ação da sociedade sobre si mesma'” (1996, p. 320). Assim, essa política republicana descrita por Tocqueville em A Democracia na América mostrava um espaço público preenchido por instituições nas quais as pessoas podiam se reunir em suas semelhanças e diferenças, tais como distritos, escolas, religiões e práticas que incentivavam as virtudes e formavam as mentes e os corações dos cidadãos requeridos por uma república democrática. "Quaisquer que sejam seus propósitos mais particulares”, escreve Sandel, "essas agências de educação cívica inculcam o hábito de dar atenção aos assuntos públicos. E ainda, dada a sua multiplicidade, elas impedem a vida pública de se dissolver em um todo

14 Considerações sobre o governo da Polônia, capítulo 4.

15 Ver o Emílio, livro 1.

\begin{tabular}{|l|l|l|l|l|}
\hline Revista Dialectus & Ano 8 & n. 15 & Agosto - Dezembro 2019 & p. 288-303 \\
\hline
\end{tabular}


indiferenciado" (1996, p. 321). Logo, o filósofo conclui que sempre haverá perigos inerentes ao processo de formação cívica nas repúblicas, pois más comunidades podem formar pessoas de mau caráter, mas por mais que os liberais tenham razão em apontar esse problema, isto não significa que o republicanismo tenha de ser necessariamente exclusivista e coercitivo, uma vez que "poderes dispersos e múltiplos locais de formação cívica podem reduzir esses riscos" (Sandel, 1996, p. 321).

Ora, entre esses diversos locais de formação cívica, a religião poderia ter um papel relevante? Essa é uma questão delicada, pois as relações entre religião e política são um assunto de imensas controvérsias, não somente do ponto de vista da discussão filosófica, mas também sobre as implicações práticas das interações entre esses dois elementos nas vidas das pessoas. No tocante ao pensamento de Rousseau, muito poderia ser dito a esse respeito ${ }^{16}$, mas os pontos que pretendo abordar brevemente aqui envolvem a importância que o autor atribuiu a certas crenças como basilares à preservação da ordem civil republicana. Referindo-se ao conteúdo do capítulo sobre a religião civil no Contrato Social, ele explicou que seu objetivo foi o de "examinar como as instituições religiosas podem entrar na constituição do Estado" (Rousseau, 2003, p. 703) ${ }^{17}$, e especialmente, quais delas podem ser benéficas a uma sociedade de homens livres. Para o filósofo, cabe ao povo soberano a autoridade para decidir o que é ou não de interesse público, regra que atinge igualmente a esfera religiosa. Neste sentido, propõe Rousseau, é do interesse do Estado que todos os cidadãos sigam os preceitos de uma profissão de fé civil, menos como dogmas de uma religião propriamente falando, e mais como sentimentos de sociabilidade que fomentam os engajamentos assumidos pelos indivíduos entre si e com a sociedade. Respeitando tais preceitos, o cidadão poderia seguir as crenças de qualquer credo que desejasse - exceto, é claro, as que contrariassem a profissão de fé civil -, porque os dogmas da religião particular que ele escolhe

não interessam nem ao Estado, nem aos seus membros, a não ser na medida em que esses dogmas se ligam à moral e aos deveres que aquele que a professa é obrigado a obedecer em relação a outrem. (...) Pois, como ele [o soberano] não tem competência no outro mundo, qual seja a sorte dos súditos na vida por vir não é seu assunto, desde que eles sejam bons cidadãos nesta vida (Rousseau, 2003, p. 468) ${ }^{18}$.

A relevância disso é tão grande que, segundo Rousseau, sem os sentimentos de sociabilidade ligados a tais dogmas, seria impossível ser bom cidadão ou súdito fiel. Tais

16 Discuti mais longamente algumas das interfaces entre religião e política na obra de Rousseau no artigo "Da fundação mítica ao exercício da soberania popular: como unir vontade e entendimento?” (Moscateli, 2017). Sobre esse assunto, ver também Scott (1994) e Kawauche (2013).

17 Cartas escritas da montanha, carta I.

18 Contrato Social, livro 4, capítulo 8.

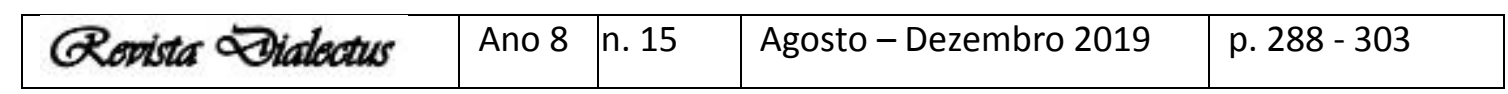


preceitos da profissão de fé civil incluem a existência de uma divindade poderosa, inteligente, beneficente, previdente e providente; a vida após a morte; a felicidade dos justos; o castigo dos maus; a santidade do contrato social e das leis; e, por fim, como único dogma negativo, a exclusão dos cultos intolerantes ${ }^{19}$.

Se avaliássemos essas propostas sobre a religião civil apenas do ponto de vista da defesa de liberdades individuais contra as ingerências das autoridades políticas - como se vê, especialmente, em teses liberais difundidas nos últimos séculos -, seria possível questioná-las como impositivas, uma vez que sua aplicação demandaria uma interferência do soberano sobre quais cultos poderiam ser praticados publicamente pelos cidadãos, algo que, para diversos críticos de Rousseau ${ }^{20}$, ultrapassa as atribuições do Estado e viola a independência que cada um deve ter em matérias de crença religiosa. Contudo, se visualizamos essa profissão de fé no panorama das concepções de liberdade civil e de virtude cívica delineadas no Contrato Social e em outras obras do filósofo de Genebra, é perceptível que seus preceitos são coerentes com o tipo de vínculo que cada pactuante deve manter com o corpo político para desfrutar de seus benefícios, o que implica direitos e deveres recíprocos a serem respeitados por todos. Trata-se, pois, de mobilizar a fé das pessoas em prol da causa comum contida na vida republicana. Para isto, a obediência à vontade geral não é somente aquilo que limita legitimamente a liberdade, mas, mais do que isto, ela é o que coloca as condições de existência da liberdade. Assim, Rousseau compreende que certas restrições à independência natural dos homens são necessárias para que, de fato, eles sejam livres e protegidos das

19 Certamente, Rousseau não foi o primeiro pensador a salientar o quanto a religião podia ser mobilizada em apoio à manutenção da ordem política. Tal recurso já aparece no contexto da Antiguidade em textos como $A$ República, de Platão, bem como na Renascença, nas reflexões de Maquiavel, e no contratualismo moderno de Thomas Hobbes. Mesmo no século XVIII, Voltaire e Montesquieu também haviam reconhecido que a crença em uma divindade e na vida após a morte representava um fator potencialmente capaz de servir de freio moral às ações dos homens. Todavia, nenhum dos dois contemporâneos de Rousseau chegou a defender o estabelecimento de uma profissão de fé por parte da autoridade civil. Em suas obras, Montesquieu manifestou-se favoravelmente a que a religião contribuísse, junto com as leis civis, para tornar os homens bons cidadãos - como se lê em $O$ Espírito das Leis, livro 24, capítulo 14 -, mas advertiu para que não misturasse, na elaboração das leis, o sagrado e o profano, isto é, para que não se estatuísse por meio de leis religiosas o que devia ser feito por leis humanas, e vice-versa, pois os dois tipos de leis possuem naturezas distintas e não convém confundi-las (ver $O$ Espírito das Leis, livro 26, capítulo 2). No tocante à crença na vida após a morte, por exemplo, Montesquieu entendia que se as pessoas se considerassem responsáveis por seu destino futuro, elas teriam em mente a necessidade de serem boas nesta vida para merecerem recompensas na próxima. Quando isto não estivesse posto nos preceitos da religião seguida pelos cidadãos, o autor propôs que competia às leis civis suprir essa falta, de modo que a severidade delas devia aumentar na medida em que os preceitos religiosos eram fracos para reprimir os crimes.

20 Entre eles o liberal Benjamin Constant, que condenou duramente a religião civil de Rousseau por vê-la como um ataque à liberdade individual: "O que é o Estado, decidindo os sentimentos que é preciso adotar? Que me importa que o soberano não me obrigue a acreditar, se ele me pune por eu não acreditar? Que me importa que ele não me atinja como ímpio, se ele me atinge como insociável? Que me importa que a autoridade se abstenha das sutilezas da teologia, se ela se perde em uma moral hipotética, não menos sutil, não menos estranha à sua jurisdição natural? Eu não conheço nenhum sistema de servidão que tenha consagrado erros mais funestos do que a metafísica eterna do contrato social” (Constant, 1961, p. 129).

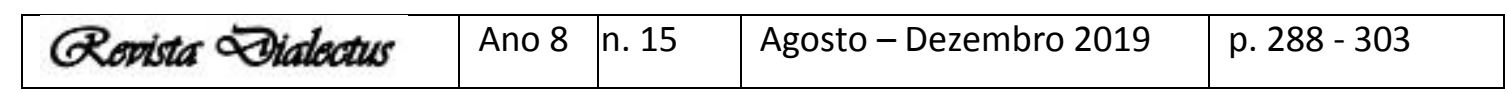


vontades arbitrárias uns dos outros. No tocante à religião, isto significa que nem todas as crenças seriam plenamente compatíveis com a coesão do Estado republicano, pois há aquelas que afastam os cidadãos do cumprimento de seus deveres, enfraquecem seus sentimentos para com a pátria e, talvez o pior dos efeitos, transformam-nos em inimigos por causa de diferenças naquilo em que acreditam. Portanto, tais crenças não seriam aceitáveis, a fim de se evitar os graves problemas que elas acarretam. Afinal, escreve o autor, a intolerância religiosa e a intolerância civil "são inseparáveis. É impossível viver em paz com pessoas que se acredita réprobas (...). Em todos os lugares onde se admite a intolerância religiosa, é impossível que não tenha um efeito civil" (Rousseau, 2003, p. 469). Ademais, não se trata, vale a pena repetir, de impedir que haja liberdade para os indivíduos aderirem a diferentes religiões, mas de fomentar um núcleo comum de crenças que sejam capazes de torná-los bons cidadãos, comprometidos com o pacto social e as leis que lhes deram sua liberdade como membros de uma sociedade política. A difusão delas faria parte, então, do trabalho formativo que, para Rousseau, edificaria em cada um a moralidade republicana, juntamente com os costumes e a opinião pública ${ }^{21}$.

Ao nos voltamos para as ideias de Sandel acerca da religião, é possível encontrar argumentos que se aproximam - pelo menos em parte - dessa forma política de pensá-la. Em Liberalismo e os limites da justiça, o filósofo critica tanto "[os] liberais que pensam que a questão dos direitos deveria ser neutra em relação a doutrinas morais e religiosas substantivas", quanto "os comunitaristas que pensam que os direitos deveriam se basear nos valores sociais prevalecentes" (Sandel, 1998, p. XI). No lugar dessas duas posições distintas sobre a questão dos direitos e da justiça, Sandel oferece outra, segundo a qual "os princípios de justiça dependem, para sua justificação, do valor moral ou do bem intrínseco dos fins aos quais eles servem" (1998, p. XI). Nessa concepção, o reconhecimento de um direito deveria resultar de se mostrar que ele honra ou promove algum importante bem humano, seja ou não este bem valorizado ou implícito nas tradições da comunidade. Essa perspectiva não é, estritamente falando, comunitarista, e sim mais bem descrita como "teleológica" ou "perfeccionista", e Sandel cita a teoria política de Aristóteles como exemplo dela, já que o pensador grego colocou a definição do "modo de vida mais desejável" como anterior à investigação da "constituição ideal".

21 Isto não significa que nas repúblicas contemporâneas a proposta do estabelecimento, pelo Estado, dos dogmas positivos dessa "profissão de fé civil" seja viável ou até mesmo aceitável pela maioria das pessoas. Dada a grande diversidade de crenças, visões de mundo, concepções éticas, filosóficas e políticas às quais elas aderem nas complexas sociedades democráticas de nosso tempo - o que Rawls chamou de "o fato do pluralismo" (2000b, p. 80) -, a demanda da adoção pública do "conteúdo mínimo" formado por esses dogmas encontraria resistências e, muito provavelmente, seria vista como uma medida de autoritarismo. 
No tocante ao direito de liberdade de crença, por exemplo, Sandel afirma que os liberais o defendem não por causa da relevância da religião em si, mas pelo valor da autonomia dos indivíduos para fazerem suas próprias escolhas no âmbito religioso. Na visão do autor, isso desconsidera a verdadeira natureza da importância que a religião tem na vida das pessoas, ou seja, como algo cuja observância

é um fim constitutivo, essencial para seu bem e indispensável para a sua identidade. Alguns podem ver suas crenças religiosas como uma questão de escolha, outros não. O que torna a crença religiosa digna de respeito não é seu modo de aquisição - seja a escolha, a revelação, a persuasão ou o costume -, mas seu lugar em uma vida boa, ou as qualidades de caráter que ela promove, ou (de um ponto de vista político) sua tendência a cultivar os hábitos e disposições que produzem bons cidadãos (Sandel, 1998, p. XII).

Caso não se perceba essa especificidade da questão religiosa, ela corre o risco de ser tratada como mais um mero assunto de preferência pessoal, tendo o mesmo peso que outras preferências de tipo bem distinto. Assim sendo, as leis teriam que dar os mesmos direitos a quem age por escolhas religiosas ou de outras naturezas ${ }^{22}$. Consequentemente, pondera Sandel, assimilar a liberdade religiosa à liberdade em geral reflete o desejo liberal de neutralidade, mas não é a melhor forma de lidar com o problema, pois

ele confunde a busca de preferências com o cumprimento de deveres. Logo, ele ignora a preocupação especial acerca da liberdade religiosa com a situação de eus conscientemente onerados - os quais reivindicam deveres que eles não podem escolher abandonar, mesmo em face de obrigações civis que conflitam com tais deveres (Sandel, 1998, p. XIII).

Sandel prossegue dizendo que não pretende que o Estado reconheça e apoie quaisquer demandas de cunho religioso, já que várias delas podem ser preconceituosas e prejudiciais à sociedade. Neste sentido, o livre exercício de práticas religiosas merece proteção especial se elas "produzem modos de ser e de agir que são dignos de honra e apreciação" (Sandel, 1998, p. XIII-XIV), sendo, portanto, admiráveis em si mesmos ou por estimularem qualidades de caráter apropriadas à cidadania. Na ausência de razões para pensar que a liberdade religiosa gera esses bons efeitos, sua defesa fica enfraquecida, embora se possa dar outras justificativas para ela. Contudo, conclui Sandel, "a questão do direito não pode ser inteiramente desligada de um julgamento substantivo sobre o valor moral da prática que ele protege" (1998, p. XIV).

22 Entre os exemplos de reivindicações de direitos especiais por razões religiosas mencionados por Sandel está o da permissão para quebrar códigos oficiais de vestimenta, como no caso de judeus que usam o solidéu no exercício de funções públicas, ou o das muçulmanas que usam o véu em escolas; também o das exceções às leis restritivas do uso de drogas no tocante a substâncias que fazem parte de rituais religiosos, como o peiote para tribos indígenas da América do Norte; ou ainda, o da licença da obrigação de exercer atividades profissionais em certos dias, como a isenção de trabalhar no sábado, para os judeus.

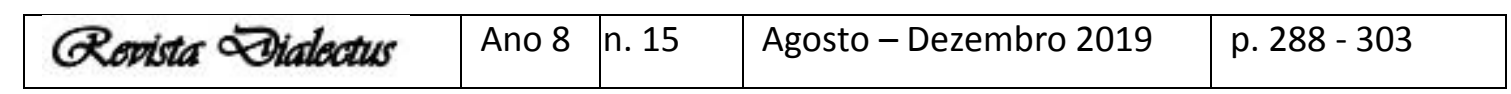


Como se vê, cada qual a seu modo, Rousseau e Sandel buscaram defender a importância da religião no âmbito político por seus possíveis bons efeitos morais em termos de promoção do civismo. Na medida em que gera laços de solidariedade entre as pessoas, respeito mútuo, sentido de dignidade própria, observância dos deveres e interesse pelo bem comum, o sentimento religioso mostra-se aos dois filósofos como essencial não apenas para solidificar os valores necessários à vida republicana, mas também para mobilizar os cidadãos contra as injustiças que eles veem sendo cometidas. Dois exemplos mencionados por Sandel são ilustrativos disso, ambos extraídos da história dos EUA.

O primeiro refere-se aos debates sobre a abolição da escravidão ocorridos no país nas décadas de 1830 e 1840. Sandel aponta que muitos abolicionistas cristãos defendiam a crença de que a escravidão era um pecado horrendo aos olhos de Deus, e que por isto tinha de ser banida das leis da nação. Neste sentido, sua fé ajudou a formatar seu discurso político contra o tratamento injusto dado a milhares de pessoas, pois eles incorporaram a crença expressa na Declaração de Independência dos EUA, segundo a qual todos os homens foram criados iguais e dotados por Deus de certos direitos inalienáveis, entre eles a vida, a liberdade e a busca da felicidade. Sandel comenta que, na visão de John Rawls, o uso de argumentos religiosos por esses abolicionistas cristãos não violava os limites da razão pública liberal, na medida em que viviam em uma sociedade que ainda não era bem-ordenada. Ao agirem assim, eles teriam contribuído "para produzir uma sociedade na qual a discussão pública seja conduzida somente em termos de 'valores políticos'. Os argumentos religiosos dos abolicionistas podem ser justificados por acelerarem o dia em que argumentos religiosos não mais desempenhariam um papel significativo no discurso público" (Sandel, 1998, p. 213). Entretanto, Sandel considera que essa interpretação de Rawls não deve nos levar ao equívoco de pensar que esses abolicionistas estivessem usando o discurso da religião como um simples instrumento para fins políticos, ou buscando criar uma sociedade na qual argumentos religiosos fossem banidos das discussões públicas. Muito pelo contrário, o mais provável é que eles quisessem mostrar que não apenas a escravidão, mas outras questões políticas relevantes também deviam ser examinadas sob a perspectiva de argumentos morais e religiosos, de um modo que se afasta da proposta liberal rawlsiana ${ }^{23}$.

23 As observações de Sandel referem-se à discussão dos limites da razão pública realizada por Rawls em $O$ liberalismo político, onde essa razão é entendida como "o debate dos cidadãos no espaço público sobre os fundamentos constitucionais e as questões básicas de justiça” (Rawls, 2000b, p. 52). Nesta obra, o autor afirma que embora de modo geral, quando se trata de questões políticas fundamentais, as razões explicitamente oferecidas em termos de doutrinas abrangentes (como as das religiões) não devam ser introduzidas na esfera da razão pública, no caso de uma sociedade que ainda não seja bem ordenada, seria permitido que os cidadãos apresentem "aquilo que consideram a base dos valores políticos enraizados em sua

\begin{tabular}{|l|l|l|l|l|}
\hline Govista Qialectus & Ano 8 & n. 15 & Agosto - Dezembro 2019 & p. 288-303 \\
\hline
\end{tabular}


O segundo exemplo que pode ser extraído da obra de Sandel remete aos movimentos pelos direitos civis dos negros nas décadas de 1950 e 1960. Embora eles costumem ser interpretados sob a ótica do liberalismo como reivindicações por direitos individuais e igualdade perante a lei, o autor considera que eles estão entre as mais significativas expressões da política republicana, uma vez que representam "um momento de empoderamento, um exemplo da corrente cívica da liberdade", uma verdadeira luta pela liberdade republicana, a qual "consiste em agir coletivamente para moldar o mundo público" (Sandel, 1996, p. 348). É importante lembrar que vários dos principais ativistas envolvidos nesse movimento eram também líderes cristãos, entre eles o pastor batista Martin Luther King Jr., que configurou seus discursos e suas estratégias de combate à segregação dos negros a partir de suas crenças religiosas, pregando protestos não violentos e a desobediência civil como formas de promover mudanças nas leis e nas consciências dos cidadãos americanos. No entendimento de Sandel, o

aspecto formativo da política requer espaços públicos que reúnam os cidadãos, capacite-os para interpretar sua condição e cultivar solidariedade e engajamento cívico. Para o movimento dos direitos civis, esses espaços públicos foram fornecidos pelas igrejas negras do Sul. Elas eram os lugares de encontros de massa, da educação cívica, de oração e música, que prepararam os negros para aderir aos boicotes e às marchas do movimento (1996, p. 349).

Dessa maneira, recorrendo-se à importância da religião nas vidas dos membros de comunidades negras, realizava-se um processo educativo que implicava na transformação moral e cívica do povo, revelando aos oprimidos e discriminados a força política que suas ações coletivas poderiam demonstrar. Martin Luther King Jr. acreditava que eram justamente essas ações que poderiam dar aos negros a dignidade que lhes era negada em outros âmbitos.

Esses dois exemplos revelam o quanto as virtudes necessárias ao exercício da liberdade republicana podem ser adquiridas, segundo Sandel, a partir de vínculos religiosos, o

doutrina abrangente, desde que o façam de maneiras que fortaleçam o ideal da própria razão pública" (Rawls, 2000b, p. 299). Assim, no contexto dos Estados Unidos da primeira metade do século XIX, Rawls considerava que, pelo menos de um ponto de vista conceitual - sem entrar na questão histórica propriamente dita -, os abolicionistas que empregavam a fé cristã no combate à escravidão não estavam indo contra o ideal da razão pública, pois "poderiam ter entendido suas ações como a melhor forma de chegar a uma sociedade bem-ordenada e justa, na qual o ideal de razão pública pudesse vir a ser respeitado" (2000b, p. 301). Ele admite que nem sempre as pessoas conseguem discernir claramente as razões abrangentes oriundas de seus credos pessoais, por exemplo, e as razões públicas que advém de uma concepção política fundamentada independentemente de doutrinas religiosas e morais: "No entanto, podem ser levadas a reconhecer essas distinções em determinados casos. Os abolicionistas poderiam dizer, por exemplo, que apoiavam os valores políticos da liberdade e da igualdade para todos, mas que, dadas as doutrinas abrangentes que professavam e as doutrinas correntes em sua época, era necessário invocar as razões abrangentes nas quais uma grande maioria acreditava que aqueles valores estivessem baseados. Dadas essas condições históricas, não deixava de ser razoável que agissem da forma como agiram em nome do próprio ideal de razão pública" (Rawls, 2000b, p. 302-303). É dessa conclusão que Sandel discorda.

\section{9}


que demonstraria, na visão do autor, a falha do liberalismo político em colocar as doutrinas morais e religiosas dos cidadãos para fora das discussões públicas sobre questões de justiça e de direito. Os prejuízos dessas restrições à razão pública, diz ele, estão se tornando bem evidentes em países como os EUA, mas Sandel não acredita que a política democrática possa manter uma vida pública desse tipo sem consequências negativas, entre elas o próprio desencantamento com a política. "Onde o discurso político carece de ressonância moral, a ânsia por uma vida pública de significados maiores encontra expressões indesejáveis" (Sandel, 1998, p. 217), escreve o filósofo, tais como o moralismo intolerante e fundamentalista de grupos religiosos, ou então uma preocupação exagerada dos cidadãos com os vícios privados dos agentes públicos, a qual é estimulada pela cobertura sensacionalista da mídia alimentada por escândalos sucessivos. Apesar de o liberalismo político não ser o único culpado por esses problemas, Sandel denuncia que sua forma de razão pública ajuda a criar um vácuo moral que acaba sendo preenchido pelo "intolerante, pelo trivial e por outros moralismos mal orientados" (1998, p. 217) ${ }^{24}$.

Talvez seja correta a hipótese de que tais problemas não surgem apenas em países onde o liberalismo político tem maior ressonância, a exemplo dos EUA, mas mesmo em um Estado como o Brasil, no qual a ausência de uma cultura republicana enraizada entre os cidadãos também abre margem para discursos moralistas e religiosos intolerantes, dirigidos contra a diversidade de pensamento nas instituições de ensino ou as diferenças nas orientações sexuais seguidas pelas pessoas, por exemplo. Muitas vezes, mesclados à bandeira do combate à corrupção no sistema político ou à denúncia da presença de supostas "ideologias" prejudiciais na educação pública, esses discursos incorporam o que há de pior em suas demandas, defendendo saídas autoritárias que afrontam as próprias bases da vida republicana. O tipo de virtude patriótica que eles proclamam é incompatível com a tolerância, o respeito e a solidariedade que cada um deve ter em relação a seus concidadãos na república, conforme vemos nas teses de Rousseau. Ao invés de reforçar os sentimentos de sociabilidade e o interesse pelo bem comum necessários à formação de bons cidadãos, esses discursos - e as práticas perniciosas que eles acarretam - fomentam a discriminação e a violência, dividindo a sociedade em facções inimigas incapazes de dialogar e de conviver. Para Sandel, esse é um caminho que leva à corrupção da virtude cívica, mediante o fundamentalismo demonstrado

24 Poderia ser argumentado que o liberalismo de Rawls não exclui completamente as doutrinas abrangentes das discussões políticas, uma vez que o consenso sobreposto necessário à estabilidade da justiça como equidade proposta por ele implica que os cidadãos em geral deem seu apoio à concepção de justiça apropriada a uma democracia constitucional, mas cada um a partir da doutrina razoável que adota. Esse é um ponto que, por razões de delimitação do artigo, não vou desenvolver aqui. Para maior aprofundamento, ver especialmente a "Conferência IV - A ideia de um consenso sobreposto" em O liberalismo político.

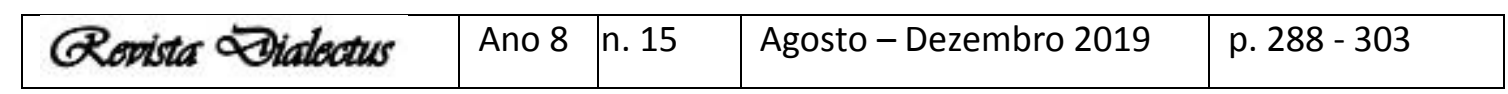


por aqueles que não conseguem conviver com a pluralidade democrática e desejam banir o que for diferente deles mesmos.

Assim, se conforme Sandel a política republicana deve conceder espaço para que as doutrinas morais e religiosas dos cidadãos ajudem a prepará-los para a participação nas questões públicas, ele enfatiza que isso somente tem bons resultados onde há respeito mútuo entre os adeptos de diferentes doutrinas. Frente a essa necessidade, o autor distingue o que qualifica como uma concepção liberal de respeito mútuo, por um lado, pela qual respeitamos as doutrinas abrangentes de outrem simplesmente as ignorando para propósitos políticos, e, por outro lado, o que seria uma concepção deliberativa, pela qual "respeitamos as convicções morais e religiosas de nossos concidadãos adotando-as ou observando-as - às vezes, desafiando-as e contestando-as, às vezes, escutando-as e aprendendo com elas -, especialmente quando essas convicções tocam em importantes questões políticas" (Sandel, 1998, p. 217). Tal concepção deliberativa, Sandel reconhece, pode não levar os envolvidos a apreciar ou a concordar com as convicções morais e religiosas dos outros; talvez até aumente a aversão a elas. Porém, apesar disso, o filósofo pensa que se trata de um ideal mais adequado para uma sociedade pluralista do que o proposto pelo liberalismo, pois ele "nos capacita melhor para apreciar os bens distintos que nossas vidas diferentes expressam" (Sandel, 1998, p. 218$)^{25}$.

Por fim, Sandel entende que se os liberais estivessem corretos sobre a possibilidade de haver liberdade desligada do autogoverno, bastaria que os indivíduos fossem capazes de escolher seus próprios fins e tolerar as escolhas dos outros, e então não seria preciso correr os riscos da formação cívica republicana, com suas implicações morais e até mesmo religiosas. Entretanto, como vimos, Sandel elenca uma série de problemas que esse liberalismo acarretaria, tais como a desvalorização das obrigações morais e políticas advindas dos vínculos com as comunidades, a restrição da importância desses vínculos à vida privada, e

25 Ao comparar a concepção de tolerância "não crítica" (non-judgemental toleration) de Rawls à concepção "crítica" (judgemental toleration) de Sandel, Mauricio Correa Casanova entende que "en general la crítica de Sandel a la tolerancia minimalista o pragmática de Rawls lleva en parte razón, en el preciso sentido de que al poner entre paréntesis o evitar la discusión en el lenguaje del bien se presupone que todas las doctrinas comprehensivas tienen la capacidad para traducir de forma no contradictoria sus propias exigencias morales a la luz de los valores políticos que son el centro de la razón pública política. Dado este hecho, a mi entender, el balance de valores políticos no deja de ser inmune a la crítica, de tal modo que esto pueda conducir en un determinado momento a una reformulación de ciertas leyes ya establecidas. Como hemos advertido, tal parece que la virtud de los argumentos puramente políticos e imparciales de la razón pública más bien parecen inmunizar el debate político y jurídico, evitando (so pretexto de tolerancia) la crítica moral proveniente de puntos de vista no liberales. En definitiva, esto hace que, como sostiene Sandel, la tolerancia liberal no cultive la apreciación por los tipos de vida que permite, y tan sólo respete los yoes de las vidas que existen. En el fondo, se trata de una tolerancia que agoniza moralmente en el momento de atribuirle a nuestras vidas privadas algún sentido extra individual o comunitário" (2006, p. 117).

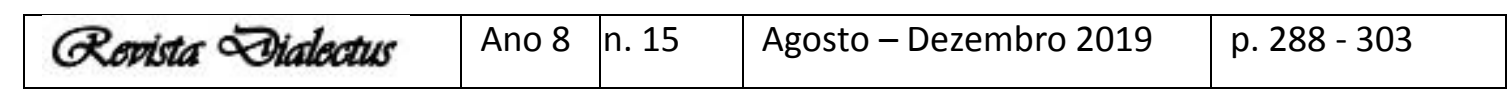


a distinção entre os princípios da justiça e as concepções de bem dos cidadãos. Desse modo, nos domínios da neutralidade do Estado e da república procedimental, proliferaria o desinteresse pela política e a sensação de desempoderamento do cidadão comum. E como Rousseau já havia alertado no Contrato Social, "[1]ogo que alguém diz, das questões do Estado, 'o que me importa?', devemos reconhecer que o Estado está perdido" (2003, p. $429)^{26}$. Por isto, Sandel considera que o projeto republicano ainda se mostra fundamental para enfrentar o descontentamento democrático, pois pode inspirar o engajamento moral e cívico que o autogoverno e a liberdade requerem.

\section{REFERÊNCIAS:}

BERNARDI, Bruno. Rousseau: «La volonté générale, entre raison publique et passions sociales ». 2010. Disponível em: https://www.ajef.net/j-j-rousseau-la-volonte-generale-entreraison-publique-et-passions-sociales/. Acessado em: 12/04/2019.

CASANOVA, Mario Correa. Dos versiones rivales sobre la tolerância: La crítica de Michael Sandel a John Rawls. Veritas, v. I, n. 14, p. 97-119, 2006.

CONSTANT, Benjamin. Principes politiques. Paris: INALF, 1961.

KAWAUCHE, Thomaz. Religião e política em Rousseau: o conceito de religião civil. São Paulo: Humanitas; FAPESP, 2013.

MONTESQUIEU. Euvres complètes. Paris: Gallimard, 2001. V. 2.

MOSCATELI, Renato. Por que Emílio não é o cidadão republicano. Argumentos, v. 4, n. 8, p. 135-149, 2012.

Da fundação mítica ao exercício da soberania popular: como unir vontade e entendimento? Philósophos, v. 22, n. 1, p. 163-192, jan./jun. 2017.

RAWLS, John. Uma teoria da justiça. Trad. Almiro Pisetta e Lenita M. R. Esteves. São Paulo: Martins Fontes, 2000(a).

2000(b).

O liberalismo político. 2. ed. Trad. Dinah de Abreu Azevedo. São Paulo: Ática.

REIS, Cláudio Araújo. Vontade geral e decisão coletiva em Rousseau. Trans/Form/Ação, Marília, v. 33, n. 2, p. 11-34, 2010.

ROUSSEAU, J.-J. Emílio ou da educação. Trad. Roberto Leal Ferreira. São Paulo: Martins Fontes, 1999.

Euvres complètes. Paris: Gallimard, 2003. v. 3.

SANDEL, Michael J. Democracy's discontent. Cambridge; Londres: The Belknap Press of Harvard University Press, 1996.

Liberalism and the limits of justice. 2. ed. Nova York: Cambridge University

26 Livro 3, capítulo 15.

\begin{tabular}{|c|c|c|c|c|}
\hline Rovista Q Dialectus & Ano 8 & n. 15 & Agosto - Dezembro 2019 & p. $288-303$ \\
\hline
\end{tabular}


Press, 1998.

SCOTT, John T. Politics as imitation of the divine in Rousseau's Social Contract. Polity, v. 26, n. 3, p. 473-501, 1994.

\begin{tabular}{|l|l|l|l|l|}
\hline Q Povista Dialectus & Ano 8 & n. 15 & Agosto - Dezembro 2019 & p. $288-303$ \\
\hline
\end{tabular}

